\title{
Shira L. Lander Ritual Sites and Religious Rivalries in Late Roman North Africa
} (Cambridge: Cambridge University Press, 2016), hardcover, xvii +253 pp.

\author{
ROBIN M. JENSEN \\ rjensen3@nd.edu \\ University of Notre Dame, Notre Dame, IN 46556
}

Lander's study focuses on a particular region of the Roman Empire-North Africa - and a particular time - the fourth-sixth centuries. She chose to concentrate on this area because, in her words, it both has seldom been studied and was a place where narratives of spatial contestation were particularly rooted in intraChristian strife and then applied to "paradigms of relations with non-Christians" (p. 2). Her selection not only anchors her arguments in a specific time and place but the choice makes good sense.

During this time, this part of the world was especially embroiled in struggles for religious dominance. Some of the results of this were confiscation, destruction, desecration, and appropriation of temples, churches, altars, synagogues, and divine images. These acts not only targeted different religious communities but also rival Christian groups (e.g., Catholics vs. Donatists or Arian Vandals vs. African Nicenes). In some cases these incidents were less violent or frequent than one might gather from the propagandistic rhetoric of the victims or triumphalist claims of the perpetrators, but this actually makes the circumstances more fascinating. Furthermore, by concentrating on the ways that actual buildings came to symbolize ascendant power or political status, Lander provides concrete examples of both "architectural dispossession and spatial supersession" (p. 33). Her attention to the material evidence and fine use of archeological studies thus is not simply enrichment but is essential to her argument.

After a brief introduction to her project ("Scaffolding"), the book opens with a chapter that lays out Lander's method, sources (both ancient and modern), and underlying theories of sacred space and religious violence. It continues very coherently, moving from a study of how Christians generally regarded their places of worship (Chapter 2) to a summary of the conflicts among African Christian communities in the fourth and fifth centuries (Chapter 3). Without getting too bogged down in a synopsis of the so-called Donatist controversy, Lander keeps her eye on the ways that buildings played a symbolic role in the struggle over legitimacy, property, and claims to be the true and holy church. The final two 
chapters look beyond the internecine battles among Christian groups to examine the ways that Christians regarded both the sanctuaries of the traditional Roman cults and Jewish synagogues. Lander explores the similarities of Christian-built worship spaces with temples and the ways Christians modified those pre-existing structures for their assemblies. A particularly vivid example is the transformation of a temple cella into a baptistery (p. 212).

In Chapter 5, Lander looks closely at the evidence for Christian appropriation and repurposing of synagogues. She notes that the archaeological record for actual confiscation is thin, a problem compounded by the lack of textual evidence from actual Jewish communities in North Africa. Lander remarks on the dearth of scholarly studies of Jewish-Christian relations in that region (making special exception for Karen Stern's 2008 monograph, Inscribing Devotion and Death: Archaeological Evidence for Jewish Populations of North Africa). She also laments both the over-reliance of historians on Christian sources and their tendency to over-generalize from studies of Jews in other parts the Roman world. Nevertheless, Lander turns to the "meager" evidence provided by the Jewish synagogues at Hammam Lif in Tunisia and Lepcis Magna in Libya. Turning to non-Jewish sources, she likewise considers both African Christian writings about Jews (especially from Tertullian and Augustine) that-following the work of Paula Fredriksen-indicate a kind of "conventional co-existence" (p. 221). Similarly, Roman legislation seems to indicate a relatively low level of synagogue disturbance in Africa as compared with other regions of the Empire. Still, while acknowledging the "less prevalent" evidence for Christian synagogue dispossession, Lander concludes that the recorded words of North African Christians nonetheless reveal an adversarial narrative (p. 236).

Several excellent, recent scholarly works attend to the role of both built and natural sacred spaces (or places) in the religious practices and spiritual topography of ancient communities, be they Jews, Polytheists, or Christians. Similarly, new studies have appeared that examine the role of religiously motivated (or justified) violence in Late Antiquity. Among these, the works of Ann Marie Yasin, Anna Leone, Maijastina Kahlos, Leslie Dossey, Christine Shepardson, and Brent Shaw stand out, and have significantly advanced and complicated our ways of thinking about these matters. To this excellent group we should now add Shira Lander, whose new monograph considers these issues together to produce an illuminating study of the diverse ways rival religious communities regarded space as a tool for defining boundaries while often characterizing others' sacred places either as potentially dangerous or valuable property to be seized and occupied. The extent to which one group genuinely believed they were obliged to destroy the cult buildings or furnishings of another or whether such actions were more likely prompted by desire for basic building materials and land is one of the key questions that winds through Lander's chapters. Additionally, she explores the often-unpredictable role of imperial patronage, ecclesial and secular legislation, and elements of ethnic or social identity. These may have fueled conflicts or emboldened competing local groups, some of whom believed themselves to be victims of economic or political injustice. 
In summary, this is a fine and balanced study of the subject of religious rivalries over sacred places and religious sites. Lander's focus on the North African evidence allows a nuanced analysis that provides welcome fine-tuning to more broad discussions of the subject. I have only one serious complaint, and that is the absence of a bibliography, which would help the reader who otherwise must dig back through footnotes to find the original citation of a secondary work. This may have been the decision of the publisher and not the author and, in my view, is the only flaw in a very fine work. 